\title{
The Challenges Of Online Learning During Pandemic: Students' Voice
}

\author{
Irza Yuzulia \\ Universitas Pendidikan Indonesia \\ irzayuzulia@gmail.com

\begin{tabular}{ccc}
\hline Diterima & Direvisi & Disetujui \\
$08-01-2021$ & $27-01-2021$ & $01-03-2021$ \\
\hline
\end{tabular}

\begin{abstract}
The global spread of COVID-19 pandemic causes class suspensions resulting in the need for online learning. Online learning becomes a new challenge for the students and teachers in this pandemic situation. The present research is aimed to investigate the challenges and problems faced by the students during the implementation of online learning in this pandemic situation. The respondents of this research were 54 students in Senior High School. The results showed that the students faced some difficulties in learning online such as poor internet connection, lack of motivation, easily getting distracted, and more stress due to the teachers' amount of tasks. Regarding the positive aspect of online learning, they stated that online learning is more structured than face to face learning and they felt more confident to join online discussion. Some of the students were more comfortable to speak in online class than in face to face interaction. Overall, the students stated that they prefer traditional learning than online learning due to some difficulties they faced during the implementation of online learning. It is hoped that the teacher can deliver interesting methods and techniques in teaching online to foster students' motivation and performance in this pandemic situation.
\end{abstract}

Keywords: covid-19, online learning, Students' perception.

Abstrak - Penyebaran pandemi global COVID-19 menyebabkan penangguhan kelas yang mengakibatkan munculnya kebutuhan pembelajaran daring. Pembelajaran daring menjadi tantangan baru bagi siswa maupun guru dalam situasi pandemi ini. Penelitian ini bertujuan untuk mengetahui tantangan-tantangan dan permasalahan-permasalahan yang dihadapi siswa selama pembelajaran daring dalam situasi pandemi covid. Responden dari penelitian ini adalah 54 siswa Sekolah Menengah Atas. Hasil penelitian menunjukkan bahwa siswa menghadapi beberapa kesulitan dalam belajar online seperti koneksi internet yang buruk, motivasi belajar yang berkurang, sulit berkonsentrasi selama pembelajaran daring dan menjadi lebih stres karena banyaknya tugas yang diberikan oleh guru. Berdasrakan sisi positif dari pembelajaran daring, siswa berpendapat bahwa pembelajaran daring lebih terstruktur dibandingkan pembelajaran tradisional dan siswa merasa lebih percaya diri untuk mengikuti diskusi secara daring. Secara keseluruhan, siswa lebih menyukai pembelajaran tradisional dibandingkan pembelajaran daring disebabkan oleh kesulitan-kesulitan yang mereka hadapi selama pelaksanaan pembelajaran daring. Diharapkan bahwa guru dapat menyampaikan metode dan teknik-teknik yang menarik dalam pengajaran daring untuk menumbuhkan motivasi dan kinerja siswa untuk belajar dalam situasi pandemi ini.

Kata kunci: covid-19, pembelajaran online, persepsi siswa.

\section{INTRODUCTION}

Covid-19 has become current pandemic and WHO confirmed the cases have been increasing internationally. This pandemic has affected many sectors, including education process. In Indonesia, the number of confirmed COVID-19 has reached more than 170.000 cases on 31 August 2020 (WHO, 2020). The global spread of COVID19 pandemic causes class postponement resulting in the needs for online learning (Moorhouse, 2020). The Minister of Education and Culture of Republic of Indonesia has ordered all education units to run online learning from March 24, 2020 to maintain the health of the students, teachers and all staff (Mendikbud, 2020).
Online learning is perceived as the application of the internet in accessing materials, having interaction with contents, teachers and other students, and gaining assistance in learning process to make meaning, gain knowledge and progress through learning experience (Ally, 2008). The main points in online learning are students' attitude, perception, assessment evaluation, satisfaction and performance (Clayton, 2005; Sun, 2014). The online language learning in EFL context in class settings during the COVID-19 pandemic takes place in fully online learning because students and teachers cannot take in it. Online learning becomes a new challenge for the students and teachers in this situation. The study conducted by Mailizar et al (2020)suggested that the students' voices are essential on this issue. Therefore, this research 
aimed to explore students' perspectives and voices in online learning during pandemic situation.

The coronavirus has had a major impact on the world of education, wherewith the issuance of the government's call to jointly fight against Covid -19 by avoiding complex activities, social distancing, psychological distancing (Carducci et al., 2020), limiting going out of the house through work from Home (WFH) and maximizing activities that allow being carried out remotely through the online system (on-line). However, changing the learning method from the conventional method to the online method is certainly not an easy and simple job (Atsani, 2020). Almost all parties (students, lecturers, parents, and society) find their own problems, both in terms of skills, knowledge, habits, infrastructure, technology, time, costs and so on.

According to (Zhong, 2020), some factors like the insufficient access, the availability of the internet, the lack of technology and students' capacity to participate in digital learning and lack of proper interaction with instructors became the major effects in the implementation of online learning. Virtual classes cannot be of interest to students who are kinesthetic learners. Another major missing in online learning is conventional classroom socialization. Students only communicate with their friends digitally and cannot meet with their friends directly, and thus the realtime sharing of ideas, knowledge and information is partially missing from the digital learning world (Britt, 2006).

A study conducted by Nambiar (2020) showed that students perceived the online classes to lack quality. Things like disturbance within the flow of classes, problems in clarifying doubts, lack of interest, technical issues, and lack of motivation to attend the classes were some prominent factors reducing the effectiveness of online classes. Yang \& Cornelius (2004) in their study, found that students showed dissatisfaction with their courses when instructors were unavailable to provide technical support. The research also reported the dissatisfaction of the students once they had limited technical skills (Zhang \& Perris, 2004). Another finding from the present survey which is found to be according to previous research (O'Malley \& McCraw, 1999). was that students to enroll in online classes they initially feel that they cannot learn as much in online courses as they used to in face-to-face courses. The present study showed that students' perceptions are valuable to educational institutions getting to adapt better online mode of teaching within the future.

\section{RESEARCH METHODOLOGY}

This research belongs to qualitative research where the subjects were 54 students of twelve grade in Senior High School. For this study, the author formed a questionnaire which consists of 20 questions regarding students' perception of online classes and 4 open-ended questions. The questions assessed the general perception and experience of students about online classes. Response choices consisted of pre-defined options of agree and disagree. The data obtained through an online survey were analyzed by frequency of common students' responses and were stated in percentages. Demographic data were obtained using the Likert scale and is reported in percentage of students' responses.

\section{FINDINGS AND DISCUSSION}

In the questionnaire, the students were asked to give their opinion regarding the implementation of online learning, the tools used, internet connection, quality of discussion, teacher's preparation and some psychological questions related with students' feeling during online learning.

Table 1. Students Attitudes Regarding Online Learning

\begin{tabular}{|l|l|l|}
\hline Questions & Agree (\%) & Disagree (\%) \\
\hline I can learn effectively during online class & 32.1 & 67.9 \\
\hline $\begin{array}{l}\text { I don't have tools to learn at home (PC, Laptop, } \\
\text { Phone, etc) }\end{array}$ & 14.3 & 85.7 \\
\hline $\begin{array}{l}\text { My teacher often gives me group project during } \\
\text { online class }\end{array}$ & 58.9 & 41.1 \\
\hline It's easier to finish group work online & 42.9 & 57.1 \\
\hline $\begin{array}{l}\text { I have internet access and can use any devices for } \\
\text { online learning at home }\end{array}$ & 66.1 & 33.9 \\
\hline Online class is more effective than offline class & 5.4 & 94.6 \\
\hline Online class is more comfortable than offline class & 20 & 80 \\
\hline
\end{tabular}




\begin{tabular}{|l|l|l|}
\hline Online class saves time & 67.3 & 32.7 \\
\hline $\begin{array}{l}\text { Lack of computer skill makes me uncomfortable } \\
\text { during online class }\end{array}$ & 37.5 & 62.5 \\
\hline The quality of discussion during online class is bad & 62.5 & 37.5 \\
\hline $\begin{array}{l}\text { The transfer of knowledge more happens in online } \\
\text { class }\end{array}$ & 40 & 60 \\
\hline There is a lack of interaction during online class & 85.5 & 14.5 \\
\hline $\begin{array}{l}\text { I feel more comfortable to get involved in online } \\
\text { discussion }\end{array}$ & 30.4 & 69.6 \\
\hline $\begin{array}{l}\text { It is harder for me to understand the material in } \\
\text { online learning }\end{array}$ & 71.4 & 28.6 \\
\hline I don't feel more worried during online class & 32.7 & 67.3 \\
\hline $\begin{array}{l}\text { I easily get distracted and hard to concentrate } \\
\text { during online class }\end{array}$ & 70.9 & 29.1 \\
\hline I feel lazy and not interested during online class & 58.2 & 41.8 \\
\hline $\begin{array}{l}\text { The transfer of knowledge happens more in online } \\
\text { learning }\end{array}$ & 30.9 & 69.1 \\
\hline Online class is more structured than offline class & 78.6 & 21.4 \\
\hline
\end{tabular}

Table 2. Students' Overall Attitudes Regarding Online Learning

\begin{tabular}{|l|l|l|}
\hline Question & Yes (\%) & No (\%) \\
\hline $\begin{array}{l}\text { Overall, do you like online } \\
\text { learning? }\end{array}$ & 29.9 & 70.1 \\
\hline
\end{tabular}

Based on the results, it can be seen that $67.9 \%$ of the students felt that online learning in this pandemic situation is not effective. Based on open-ended questionnaire, most of the students stated that the main problem is the unstable connection and the ability to understand the materials given by the teacher. It should be noted that not all Indonesian students enjoy internet facilities. It is proved by $33.9 \%$ students who do not enjoy a good internet facilities.

"It is harder for me to follow online class. I live in a remote area and the connection in my place is very awful."

"I often miss the lesson because my internet connection is really bad. I'm so stressed."

"I don't understand most of the materials because the teacher often explains too fast."

Most of the students stated that they do not understand most of the materials since the teacher explains so fast. It is due to the time limit given by the government where one subject should be taught in one hour only. Besides that, the students stated that some of the teachers only gave them the tasks without giving any explanation. They found it hard to understand the materials in some subjects such as mathematics, chemistry and physics which need further explanation from the teacher.
Most of the students $(69.6 \%)$ stated that they disagree with the statement "I feel more comfortable to get involved in online discussion." They said that they often get distracted during online discussion and often got misunderstood by the teacher's explanation.

"I don't feel comfortable in online discussion because of the quality of discussion during online learning so much depends on the quality of internet connection".

"Sometimes we walk in the wrong paths during the discussion due to misscommunication of teacher's instruction which is not really clear"

The rest of the students agreed that they are more comfortable with online discussion because they feel more confident in online discussion. However, $62.5 \%$ of the students stated the quality of discussion during online class is bad.

"Yes, I agreed. I feel more confident of getting involved in online discussions since my friends couldn't see my face."

"Since my teacher allows us to turn off the camera, I feel more comfortable to state my opinion."

$57.1 \%$ of the students said that the qulity of online discussion is not as good as offline discussion. 
"Most of my friends remain silent when it is the time for online discussion. I don't like to be the center of attention, so I keep silent too"

"I prefer the discussion when I can see my friends in person"

Regarding the statement "I don't feel more worried during online class", $67.3 \%$ of the students disagreed with this statement. They are afraid if they do not understand the materials and do not have the chance to ask for further explanation from the teacher.

"I disagreed because I'm afraid if I do not understand the materials. As a third-grade students. I need intensive guidance from the teachers. I'm afraid if I cannot pass the final exam."

"I feel more worried because the teacher gives us more tasks. Ifeel so tired."

"I'm afraid if I get low score in the exam, I don't understand most of the materials"

Regarding the statement "how do you solve your own problem in online learning"? Most of the students solved their problem by asking their friends, joining private courses and asking the teacher personally.

"I usually ask my friends or find further explanation from youtube."

"I ask the teacher via personal chat or social media"

"My parents asked me to join private course and it is helpful to undertand the material at school more."

Based on the results, it is found that the majority of the students do not feel comfortable with online learning $(80 \%)$ and prefer to learn in conventional method.

Based on the results, it can be seen that the students are more stressed, lack motivation, and easy get bored or distracted during online learning. The teacher often gives them tasks that only require one day to collect, making them even more anxious. Based on the questionnaire results, the students complained about the techniques used by the teachers. Some of the teachers always ask them to join zoom meeting everyday which makes them bored and not interested. However, the teachers are supposed to get trained on how to make distance learning experience more interactive (McLeod, 2019; Applefield, J. M., Huber \& Moallem, 2001). They also found the teachers who did not give any explanation of the materials, only by giving the tasks. They reported that online classe was difficult to understand, lack of conceptual clarity and too many subjects scheduled in one day.

The majority of problems faced by the students were poor network connectivity, broadband issues and getting disconnected in between the classes. Although online class is the best choice, most of the students cannot afford to access the internet. The students came from various regions and some of them come from rural ares where the use of internet facilities is still difficult. Internet access in some of the respondents requires a large quota that is why during the teaching and learning process, they prefer to turn off the camera to save their quota.

The students also stated that they have health issues such as eye strain and headache since they have to join zoom meeting almost everyday. Regarding the positive aspect of online learning, they stated that online learning is more structured than face to face learning and they felt more confident to join online discussion. Some of the students were more comfortable to speak in online class than in face to face interaction. They also could watch the recorded video sent by the teacher . Finally, the other positive thing about online class is the flexibility of time and place where they can join the class anywhere.

To sum up, most of the students stated that they prefer to learn in conventional learning than in online learning due to some problems they faced during the implementation of online class during pandemic situation.

\section{CONCLUSION}

Based on the description and discussion above, it can be concluded that online learning still encountering many problems. Not only cultural conditions of the students that have not been able to follow online learning system, but also the technical problems such as the availability of learning facilities. It is necessary to expand the internet network in areas where the network is not yet available, especially in rural areas by the internet provider or the government, and improve the quality of networks for existing networks. The study also reported that the students lost their motivation during the learning process. Apart from being limited internet access, the students also feel that conventional learning is easier than online learning. They consider the lessons given by the teacher through online learning is less optimal. The teachers mostly send the materials without giving any further explanation which makes the students more anxious because they cannot understand the lesson fully. 
Online learning is proving helpful in safeguarding students' health but it is not as effective as conventional learning in the practice. Teachers and students' interaction and comfort during online class determine the success or failure in online mode of education. Teacher's creativity in designing interesting and engaging techniques in teaching also powerful to make the students interested in online learning. In addition, the teachers should be able to create a learning atmosphere that is not boring and effective in terms of the knowledge transfer method used.

\section{REFERENCES}

Ally, M. (2008). Foundations of Educational Theory for Online Learning. The Theory and Practice of Online Learning Press. (Edmonton (ed.); 2nd ed.). AU Press.

Applefield, J. M., Huber, R., \& Moallem, M. (2001). Constructivism in Theory and Practice: Toward a Better Understanding. The High School Journal, 84(2), 35-53.

Atsani, K. L. G. M. Z. (2020). Transformasi media pembelajaran pada masa Pandemi COVID19. Al-Hikmah, 1(1), 82-93.

Britt, R. (2006). ). Online education: A survey of faculty and students. Radiologic Technology, 3(77), 183-190.

Carducci, A., Federigi, I., Dasheng, L., Julian R, T., \& Marco, V. (2020). Making waves: Coronavirus detection, presence and persistence in the water environment: State of the art and knowledge needs for public health. Water Research, 179, 115907. https://doi.org/10.1016/j.watres.2020.115907

Clayton, J. F. (2005). Online learning. Encyclopedia of Human Computer Interaction, 435-440. https://doi.org/10.4018/978-1-59140-5627.ch066

Mailizar, Almanthari, A., Maulina, S., \& Bruce, S. (2020). Secondary school mathematics teachers' views on e-learning implementation barriers during the COVID-19 pandemic: The case of Indonesia. Eurasia Journal of Mathematics, Science and Technology Education, 16(7). https://doi.org/10.29333/EJMSTE/8240

McLeod, S. (2019). Constructivism as a theory for teaching and learning. https://www.simplypsychology.org/constructi vism.html
Mendikbud. (2020). Surat Edaran Mendikbud: Pembelajaran secara Daring dan Bekerja dari Rumah dalam Rangka Pencegahan Penyebaran Corona Virus Disease (COVID19).

http://kemdikbud.go.id/main/files/download/c 5d9f0ec9ff40c6

Moorhouse, B. L. (2020). Adaptations to a face-toface initial teacher education course 'forced' online due to the COVID-19 pandemic. Journal of Education for Teaching, 00(00), $1-3$.

https://doi.org/10.1080/02607476.2020.17552 05

Nambiar, D. (2020). The impact of online learning during COVID-19: Students' and teachers' perspective. The International Journal of Indian Psychology, 8(2), 783-793.

O’Malley, J., \& McCraw, H. (1999). Students Perceptions of Distance Learning, Online Learning and the Traditional Classroom. Online Journal of Distance Learning Administration, 2(4), 1-12.

Sun, S. Y. H. (2014). Learner perspectives on fully online language learning. Distance Education, 35(1), 18-42. https://doi.org/10.1080/01587919.2014.89142 8

WHO. (2020). Report of the WHO-China Joint Mission on Coronavirus Disease 2019 (COVID-19).

https://www.who.int/docs/defaultsource/coronaviruse/who-china-joint-missionon-COVID-19-final-report.pdf

Yang, Y., \& Cornelius, L. F. (2004). Students' Perceptions towards the Quality of Online Education: A Qualitative Approach. Association for Educational Communications and Technology, 861-877.

Zhang, W. Y., \& Perris, K. (2004). Researching the efficacy of online learning: A collaborative effort amongst scholars in Asian open universities. Open Learning, 19(3), 247-264. https://doi.org/10.1080/026805104200028011 0

Zhong, R. (2020). The coronavirus exposes education's digital divide. The New York Times.

https://www.nytimes.com/2020/03/17/technol ogy/china-schools-coronavirus.html 